\title{
Litter as a filter for germination in semi-arid Stipa tenacissima steppes
}

\author{
Tormo ${ }^{\mathrm{a}, *}$, Amat $\mathrm{B}^{\mathrm{b}}$, Cortina $\mathrm{J}^{\mathrm{b}}$ \\ a Area of Ecology, Department of Agrarian and Environmental Sciences, Technological College, Agri-food and Environment, University of Zaragoza, Ctra. de Cuarte S/n, 22071, Huesca, Spain \\ ${ }^{\mathrm{b}}$ University of Alicante Department of Ecology and IMEM Ap, 99 03080, Alicante, Spain
}

\section{A R T I C L E I N F O}

\section{Keywords}

Drylands

Mediterranean

Spatial heterogeneity

Regeneration

Facilitation

Nurse effect

Pistacia lentiscus

Brachypodium retusum

\begin{abstract}
A B S T R A C T
Woody species play a key role in Stipa tenacissima steppes, they affect ecosystem functioning, facilitate establishment of other plants and increase plant richness. Among the mechanisms involved in facilitation, effect of litter on seed germination and seedling establishment is largely underexplored. We studied the properties of the litter layer under five woody species common in Stipa tenacissima steppes, and assessed its effect on the germination of seeds of two key species with contrasting ecological strategy and seed morphology (the perennial grass Brachypodium retusum and the resprouting shrub Pistacia lentiscus). Litter accumulation was highest under Quercus coccifera and Pinus halepensis, and lowest under Rhamnus lycioides. Pistacia lentiscus and Rosmarinus officinalis showed intermediate levels. Litter accumulation hampered germination, particularly when seeds were sown over the litter. Litter of all species but Rhamnus lycioides reduced germination when seeds were under the litter. Litter extracts had no effect on germination. The effect of litter was largely independent of seed type. Our results show that litter has an overall negative effect acting as a physical barrier for. Litter may influence the balance between facilitation and interference. Its relation with species traits and its impact on habitat heterogeneity and community assemblage deserves further attention.
\end{abstract}

\section{Introduction}

In drylands, woody species form vegetation patches that modify the environment under their canopies. Under these patches, temperature is commonly lower and moisture is higher, which buffers the environmental stress for seedlings (Holmgren et al., 2010; Tracol et al., 2011). This effect is essential for seedlings to survive drought periods (Gómez-Aparicio et al., 2004). In addition, patches may increase soil fertility (Holmgren et al., 2010; Pugnaire and Padilla, 2006), provide protection from herbivores (Baraza et al., 2006), and enhance seed availability by attracting seed dispersers (Pausas et al., 2006; Castillo-Escrivà et al., 2019), which amplify the effects of environmental stress amelioration. Considering that patch cover is often low, patch-forming species can be considered to act as keystone species (Hurlbert, 1997; Rolo et al., 2016).

Stipa tenacissima steppes cover $70,000 \mathrm{~km}^{2}$ in the western Mediterranean basin. In these habitats, patches of woody species increase vascular plant richness, facilitate seedling establishment, and affect ecosystem composition and functioning (Amat et al., 2015; Doblas-Miranda et al., 2009). For this reason, planting patch-forming species has been recommended to restore degraded $S$. tenacissima steppes (Cortina et al., 2011; Navarro, 2006). Indeed, positive plant-plant interactions have a great potential for restoration, but we still must understand them fully to be incorporated into management practices (Maestre and Cortina, 2004a,b; Cortina et al., 2011) while most studies on plant-plant interactions in drylands involved planting experiments (Castro et al., 2004; Gómez-Aparicio et al., 2004; Maestre et al., 2001), comparatively, our understanding of the impact of nurse species on seed germination is poorer.

Leaf litter plays contrasting roles in the early stages of plant recruitment. Negative effects have been described during germination and later stages. For example, litter may inhibit seed germination and seedling emergence by reducing the amount and quality of light reaching the seeds (Facelli and Pickett, 1991; Navarro-Cano, 2007), litter can also hamper seed-soil contact and hence imbibition required for germination (Rotundo and Aguiar, 2005) and may host herbivorous fauna and create suitable environments for pathogenic fungi (García-Guzmán and Benítez-Malvido, 2003). Conversely, litter may enhance germination and seedling establishment of shade-tolerant species with large seeds, by protecting them from excessive radiation, reducing evaporation and water stress, and protecting seeds against predation (López-Barrera and González-Espinosa, 2001; Reader, 1993). Nutrient mineralization in lower horizons of the litter layer may benefit seedling establishment and growth (Boeken and Orenstein, 2001;

\footnotetext{
${ }^{*}$ Corresponding author.

E-mail address: jtormo@unizar.es (T. J)
} 
Brearley et al., 2003), whereas nutrient immobilization in early stages of litter decomposition may impair seedling nutritional balance (Facelli and Pickett, 1991b; Noble and Randall, 1999). Finally, litter may release phytotoxic compounds with deleterious effects on seed germination and seedling establishment (Bonanomi et al., 2006; Herranz et al., 2006). As the effect of litter on germination is species-dependent, litter will favour germination of some species and inhibit germination of others. Hence, at the community level, litter may affect species diversity and community structure by acting as an ecological filter for germination and early establishment (Gazol and Ibáñez, 2010; Lamb, 2008). Indeed, litter may be involved in indirect plant interactions (Facelli and Pickett, 1991b, 1991c). Variations in litterfall amount and litter quality, and changes in litter accumulation, may affect the balance between positive and negative plant-plant interactions (Ruprecht et al., 2010; Sayer, 2006).

Numerous studies describe litter accumulation in arid and semiarid areas (Descheemaeker et al., 2006; Kavvadias et al., 2001). In these environments, spatial heterogeneity of litter accumulation is large as a result of spatial heterogeneity in soil properties, plant cover and species composition (Cortina and Maestre, 2006; Whitford, 2002). Litter accumulates preferentially under woody patches (Boeken and Orenstein, 2001), and may act as physical barrier for germination (Navarro-Cano et al., 2009; Yuan et al., 2016), chemical filter (Alrababah et al., 2009; Fernandez et al., 2008) or both (Callaway et al., 1991). In other cases, positive effects of litter on seedling density and biomass prevail (Boeken and Orenstein, 2001; Bosco et al., 2018). To our knowledge, studies on the effect of patch-forming species on seed germination by means of litter accumulation are scarce (but see Rotundo and Aguiar, 2005).

We described the litter layer under common woody species in $S$. tenacissima steppes and we performed a series of laboratory experiments to understand the mechanical and chemical effect of litter type, properties and amount on the germination of two key species with contrasted ecological strategy and seed morphology and size: a patch-forming resprouting shrub (Pistacia lentiscus L.) and a widespread perennial grass (Brachypodium retussum (Pers.) P. Beauv.). We tested 1) seed germination on top of the litter layer, 2) seed germination underneath the litter layer, and 3) the effect of litter extracts on seed germination. Measuring seed germination rate and the relative interaction intensity index, RII.

\section{Materials and methods}

\subsection{Study site and species}

We characterized litter accumulation and collected litter samples under five common patch-forming woody species with contrasting litter accumulation patterns: Quercus coccifera L., P. lentiscus L., Rosmarinus officinalis L., Pinus halepensis Mill and Rhamnus lyciodes L. Aqueous extracts of $R$. officinalis litter hinder seed germination, whereas $P$. halepensis litter hampers seedling establishment (Navarro-Cano et al., 2009; Chen et al., 2013).

For each litter source species, we selected eight adults of average size, all forming monospecific patches, to maximize litter homogeneity. These individuals were located at least $50 \mathrm{~m}$ apart, and were scattered in slopes and abandoned crop fields in an area covering $10 \mathrm{~km}^{2}$ in $\mathrm{Al}-$ icante (Southeastern Spain). This area has semiarid Mediterranean climate, with an average annual rainfall of $332 \mathrm{~mm}$ and an average temperature of $17.1{ }^{\circ} \mathrm{C}$ (San Vicente del Raspeig Station; Rivas-Martínez et al., 2011). We used seeds of $P$. lentiscus and Brachypodium retusum (Pers.) P. Beauv., two widespread species in the study area with contrasting traits. Pistacia lentiscus is a resprouting perennial shrub that forms large woody patches. Brachypodium retusum is a perennial grass that appears inside and around woody patches, and in open spaces. Seeds are morphologically distinct: seeds of $P$. lentiscus free of pulp weighting an average $0.3 \mathrm{~g}$ per seed, and cariopses of $B$. retusum weighting an average $0.003 \mathrm{~g}$, and show different germination requirements (Espejo, 2007; García-Fayos et al., 2001). Neither of them present seed dormancy (García-Fayos et al., 2001; Vidaller et al., 2018). Seeds where supplied by the Forest Seed Bank of the Region of Valencia, a public body that supplies seeds for restoration and research projects.

\subsection{Litter sampling}

Between December 2007 and January 2008, we collected two samples of organic horizons and four samples of mineral soil under each shrub patch. Organic horizons were defined as the litter layer and the underlying layer formed by decomposing organic debris. The transition from organic to mineral horizons was clearly recognizable by changes in texture and color, due to the high carbonate and low organic matter content of the mineral soil. Intact organic horizons were removed by using PVC cylinders of $5 \mathrm{~cm}$ height and $9 \mathrm{~cm}$ diameter. Once the mineral soil was reached, the cylinder containing the organic layers was carefully removed with a wide spatula, covered with a plastic wrap, and transported to the laboratory. We used $8 \mathrm{~cm}$ high cylinders to collect organic horizons of $P$. halepensis because litter thickness was larger under this species. Finally, we dug the underlying mineral soil with a shovel, to a depth of $15 \mathrm{~cm}$, and transported the samples in plastic bags to the laboratory, where soil was air-dried and sieved to increase homogeneity. Additionally, for allelopathy tests, we collected 10 cylinders of litter per species from different individuals and combined all litter samples from a given species into one sample. Litter was transported to the laboratory and air-dried. Litter and mineral soils were dry-stored, resembling natural conditions in $S$. tenacissima steppes, as surface soils become dry during extended periods in winter and summer.

\subsection{Litter accumulation}

We measured litter cover under each individual in the field (8 individuals per litter source species). We estimated litter cover by measuring the largest diameter and the largest perpendicular of each patch, and calculating the surface area of an ellipse, because in these steppes litter mostly accumulates under the projection of the canopy. We measured litter thickness in the centre of the litter patches, in their periphery and in the intermediate area (4 sampling points per location, 12 points per patch).

\subsection{Effects of litter on seed germination}

Once in the laboratory, we filled 32 PVC cylinders of $5 \mathrm{~cm}$ height and $9 \mathrm{~cm}$ diameter with mineral soil collected under each litter source species (total 160 cylinders). Then, we located the cylinders containing unaltered litter on top of the mineral soil of the corresponding species on half of the cylinders (16), and attached them with tape, thus restoring the original surface soil horizons. On the additional 16 cylinders containing mineral soil of each litter source, we attached empty cylinders on top. All cylinders were placed on plastic trays, and their location was changed over the course of the experiment. Two consecutive experiments were conducted to assess the effect of litter on the germination of seeds located on top and under it:

Experiment 1. Experiments started on July 7th' 2008. For each litter type, $B$. retusum seeds were sown on half of the cylinders of each type (8 cylinders with litter and 8 without litter per litter source species). Similarly, $P$. lentiscus seeds were sown on the remaining cylinders. We placed 50 seeds per cylinder either on the litter layer or on the mineral soil. At the onset of the experiment, we watered all cylinders with distilled water to saturation. During the experiment they were kept moist by spraying distilled water: daily during the first three days, and every 
2-3 days thereafter. The experiment lasted until no new germinations occurred (8 weeks) and was conducted under natural light and laboratory conditions (temperature ranged from 18.5 to $24.0{ }^{\circ} \mathrm{C}$ and relative humidity between 34 and 63\%). At the end of the 8-week period, we recorded the accumulated number of germinated seeds per cylinder. Seeds were not removed after germination to avoid excessive manipulation and disturbance. We considered that seeds germinated when the radicle exceeded $0.5 \mathrm{~cm}$ in length.

Experiment 2. Once Experiment 1 concluded, we removed seedlings and seeds from each cylinder, and separated the litter layer from the mineral soil with a spatula. Then, we sowed 50 seeds per cylinder on top of the mineral soil, and placed the litter back on top of them. We also sowed cylinders containing no litter. The number of cylinders with mineral soil sown with $B$. retusum used in this experiment was halved (4 cylinders per litter type) due to a lack of seeds. Watering regime was the same as in experiment 1 . The experiment lasted for four weeks, until no new germinations were detected, and was conducted under natural light and laboratory conditions (temperature ranged from 24.9 to $30.1{ }^{\circ} \mathrm{C}$ and relative humidity between 42 and 54\%). At the end of the 4-week period, we recorded the number of germinated seeds in each cylinder.

When experiment 2 concluded, we carried out a third experiment to test the effect of litter extracts on germination. We removed all seeds and litter from the cylinders. We then randomly selected 20 cylinders containing mineral soil per litter source. In each cylinder, we sowed 20 seeds of either $B$. retusum or $P$. lentiscus (10 cylinders per sown species). Every 2-3 days, half of the cylinders were watered with distilled water, and the remaining half were watered with litter extracts of the same species as the source of mineral soil. Extracts were obtained by shaking litter and distilled water for $48 \mathrm{~h}$ in an orbital shaker (Garnett et al., 2004). The amount of litter used was proportional to litter accumulation under each source species, and ranged from 0.02 to $0.2 \mathrm{~g}$ dry weight $\mathrm{mL}^{-1}$. The resulting solutions were filtered through Whatman №4 cellulose filters and stored at $4{ }^{\circ} \mathrm{C}$ until use. Solutions were prepared as needed, to avoid storing them for more than 5 days. The number of germinated seeds was recorded daily. The experiment lasted for seven weeks, until no more germinations were recorded, and it was conducted in an incubation chamber with 12 -h photoperiod, $18-24^{\circ} \mathrm{C}$ temperature and $62-79 \%$ relative humidity. Extracts were less concentrated than in other studies on allelopathical interactions (e.g., 100-200 $\mathrm{g} \mathrm{L}^{-1}$ ), in an attempt to approach natural conditions (Inderjit and Nilsen, 2003).

\subsection{Litter physico-chemical properties}

When experiments were completed, we inserted a $1.3 \mathrm{~mm}$ nylon mesh underneath the litter layer of all cylinders of the five litter source species with the help of a spatula, to facilitate weighting. This setting allowed us to measure water-holding capacity and short-term evaporation rates. Cylinders were watered to saturation and weighed. Then, they were placed in an incubation chamber in the dark, where temperature ranged from 19 to $23^{\circ} \mathrm{C}$ and relative humidity from 60 to $80 \%$. Cylinders were weighed at increasing time intervals, from $1 \mathrm{~h}$ to $132 \mathrm{~h}$, until weight stabilized. Water holding capacity was estimated as the difference between the weight of water-saturated litter and its dry weight. Short-term evaporation rate for each litter type was estimated by fitting a negative exponential function to the repeated measures of litter weight. Carbon content of the litter was quantified as half its dry weight, as contamination with mineral particles was low (Sparks et al., 1996), considering litter density measured in laboratory samples. Finally, we estimated hydrophobicity of the organic horizons by using the water drop penetration time test (Dekker and Ritsema, 1994). We deposited three drops of distilled water on randomly chosen parts of the litter surface, and recorded the time for the second drop to infil- trate. Hydrophobicity was not measured in all cylinders because litter cover was too scarce in some of them.

\subsection{Statistical analysis}

The effect of litter source species on litter properties and germination was tested by analysis of variance (ANOVA) with one fixed factor (litter source) and five levels. Which were compared among them when sowing seeds on the litter layer, under the litter layer and on mineral soil devoid of litter. Differences between means were compared using Tukey-HSD test. In addition, we assessed differences in litter thickness due to location within the litter mat by including a fixed factor with three levels (inner, middle and outer parts of the litter mat) using ANOVA and Tukey-HSD test. Litter thickness and carbon content were logarithmically transformed to meet criteria of normality and homoscedasticity.

The net effect of litter on germination rate was evaluated in both experiments by estimating the relative interaction intensity index, RII = $(\mathrm{Gh}-\mathrm{Gs}) /(\mathrm{Gh}+\mathrm{Gs})$, where $\mathrm{Gh}$ is the number of germinated seeds in the presence of litter and Gs is the number of germinated seeds without litter (Armas et al., 2004). This ratio quantifies the extent of an interaction, with defined boundaries between -1 and 1 , and it is symmetric around zero. In this study, the effect of litter on germination was either positive or negative as RII approached +1 and -1 , respectively. Student's t-test was used to assess the significance of differences between RII and zero. Germination percentages were arc-sine transformed prior to analysis.

We used Pearson correlation analysis to assess the relationship between litter properties (litter weight, litter thickness, water holding capacity and hydrophobicity) and seed germination, pooling data from all cylinders together. Variables were measured per cylinder, except for hydrophobicity. Hence the number of replicates for this study was 16 for $P$. lentiscus and 22 for $B$. retusum. All analyses were performed with the R statistical software (R Development core team, 2018).

\section{Results}

\subsection{Litter properties}

Litter properties differed among the five litter source species. Litter thickness in the inner, middle and outer part of the patches showed a similar pattern in all litter source species, being lower in the external part of the litter mat (Table 1). Rhamnus lycioides accumulated less litter than the other species, whereas $Q$. coccifera and $P$. halepensis showed the highest accumulation. Litter accumulation measured as grams of carbon per surface area under $Q$. coccifera and $P$. halepensis exceeded by more than twice the amount of litter accumulated underneath $R$. lycioides and R. officinalis (Table 1).

Water retention capacity and hydrophobicity also varied between source species. Litter of Rhamnus lycioides and P. lentiscus retained more water and showed less hydrophobicity than litter from other species. The highest hydrophobicity was observed in $Q$. coccifera and $P$. halepensis. On the other hand, short-term evaporation rate was highest in $R$. lycioides and R. officinalis, and lowest in P. halepensis (Table 2).

\subsection{Litter type and seed germination}

For both sown species, germination rate was highest when seeds were sown on $R$. lycioides litter than on the litter of other species (Fig. $1 \mathrm{~A}$ and Table S1). Brachypodium retusum germination was also higher on $P$. lentiscus litter than on litter of the remaining three source species. The net effect of litter of $R$. officinalis and $Q$. coccifera on $P$. lentiscus germination was negative when seeds were sown on the litter layer (Fig. 2 , Table S2). The net effect of $R$. lycioides litter on $P$. lentiscus germination was positive. The net effect of litter on $B$. retusum germina- 
Table 1

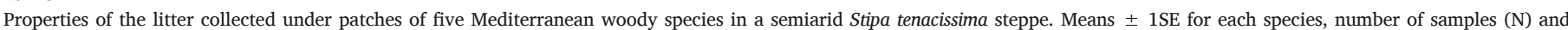

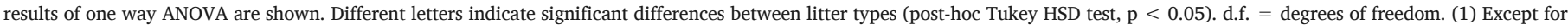
Rhamnus lyciodes, where $\mathrm{N}=6$. (2) Data for inner parts of Quercus coccifera litter layers were lost in the process.

\begin{tabular}{|c|c|c|c|c|c|c|c|c|}
\hline $\begin{array}{l}\text { Source } \\
\text { species }\end{array}$ & $\begin{array}{l}\text { Litter patch surface } \\
\text { area per individual } \\
\left(\mathrm{m}^{2}\right)\end{array}$ & $\begin{array}{l}\text { Litter } \\
\text { accumulation (g } \\
\mathrm{C} \mathrm{m}^{-2} \text { ) }\end{array}$ & $\begin{array}{l}\text { Moisture content at } \\
\text { saturation }\left(\mathrm{g} \mathrm{g} \mathrm{g}^{-1}\right)\end{array}$ & $\begin{array}{l}\text { Hydrophobicity } \\
\text { (min) }\end{array}$ & \multicolumn{2}{|c|}{ Litter thickness (cm) } & & \multirow[b]{2}{*}{ mean } \\
\hline & & & & & inner & middle & outer & \\
\hline $\begin{array}{l}\text { Rosmarinus } \\
\text { officinalis }\end{array}$ & $1.5 \pm 0.3 \mathrm{a}$ & $859 \pm 870 b c$ & $0.83 \pm 0.07 b$ & $49 \pm 14 \mathrm{ab}$ & $2.58 \pm 0.19 b$ & $1.76 \pm 0.46 b$ & $1.13 \pm 0.48 \mathrm{c}$ & $1.83 \pm 0.15 b$ \\
\hline $\begin{array}{l}\text { Quercus } \\
\text { coccifera }\end{array}$ & $14.8 \pm 3.6 b$ & $2335 \pm 240 a$ & $1.02 \pm 0.10 b$ & $113 \pm 11 a$ & $-{ }^{2}$ & $6.09 \pm 2.13 a$ & $3.13 \pm 1.87 \mathrm{ab}$ & $5.65 \pm 0.74 a$ \\
\hline $\begin{array}{l}\text { Pinus } \\
\text { halepensis }\end{array}$ & $28.2 \pm 4.0 \mathrm{c}$ & $2321 \pm 397 a$ & $0.92 \pm 0.09 b$ & $113 \pm 18 \mathrm{a}$ & $4.97 \pm 1.72 \mathrm{a}$ & $5.22 \pm 2.49 \mathrm{a}$ & $2.96 \pm 1.88 \mathrm{ab}$ & $4.38 \pm 0.68 a$ \\
\hline $\begin{array}{l}\text { Rhamnus } \\
\text { lyciodes }\end{array}$ & $3.1 \pm 0.7 \mathrm{a}$ & $616 \pm 119 b$ & $1.44 \pm 0.16 \mathrm{a}$ & $5 \pm 10 b$ & $1.42 \pm 0.63 b$ & $0.87 \pm 0.61 b$ & $0.51 \pm 0.12 \mathrm{c}$ & $0.93 \pm 0.17 b$ \\
\hline $\begin{array}{l}\text { Pistacia } \\
\text { lentiscus }\end{array}$ & $7.8 \pm 1.3 \mathrm{ab}$ & $1541 \pm 133 \mathrm{ac}$ & $1.14 \pm 0.09 \mathrm{a}$ & $35 \pm 10 b$ & $2.49 \pm 0.67 b$ & $2.08 \pm 0.54 \mathrm{~b}$ & $1.53 \pm 0.18 \mathrm{ac}$ & $2.04 \pm 0.16 b$ \\
\hline $\mathrm{N}$ & 8 & 8 & 10 & $10^{1}$ & 32 & 40 & 40 & 40 \\
\hline $\mathrm{F}$ & 18.8 & 15.6 & 5.1 & 11.9 & 17.47 & 169.41 & 42.18 & 18.12 \\
\hline ANOVA d.f. & 4,35 & 4,35 & 4,45 & 4,41 & 3,28 & 4,35 & 4,35 & 4,35 \\
\hline p-value & $<0.001$ & $<0.001$ & 0.0018 & $<0.001$ & $<0.001$ & $<0.001$ & $<0.001$ & $<0.001$ \\
\hline
\end{tabular}

Table 2

Short-term evaporation rate of different litter types estimated from the negative exponential equation $\mathrm{y}=\mathrm{a} \cdot \mathrm{e}^{-\mathrm{kt}}$, where $\mathrm{y}$ is water content $\left(\mathrm{g} \cdot \mathrm{g}^{-1}\right), t$ is drying time (hours), $k$ is evaporation coefficient and $a$ is a constant. The goodness of fit of each model and its p-value are also shown. $\mathrm{N}=10$ in all cases.

\begin{tabular}{lllll}
\hline Litter source species & $\begin{array}{l}\text { Evaporation coefficient } \\
(\mathrm{k})\end{array}$ & $\mathrm{R}^{2}$ & $\mathrm{~F}_{1,18}$ & $\mathrm{p}$-value \\
\hline $\begin{array}{l}\text { Rosmarinus } \\
\text { officinalis }\end{array}$ & 0.0173 & 0.977 & 776.847 & $<0.001$ \\
$\begin{array}{l}\text { Rhamnus lycioides } \\
\text { Quercus coccifera }\end{array}$ & 0.0285 & & & \\
$\begin{array}{l}\text { Pinus halepensis } \\
\text { Pistacia lentiscus }\end{array}$ & 0.0056 & 0.843 & 96.687 & $<0.001$ \\
& 0.0030 & 0.892 & 148.951 & $<0.001$ \\
& 0.0084 & 0.926 & 223.857 & $<0.001$ \\
\end{tabular}

tion was negative, except for $R$. lycioides litter, which had no effect. Moreover, the negative effect of litter on the germination of $B$. retusum was larger when seeds were sown on litter of $R$. officinalis, $Q$. coccifera and $P$. halepensis than on litter of $P$. lentiscus.

We observed no effect of litter type on $B$. retusum germination rate when seeds were sown under the litter layer. Germination of $P$. lentiscus seeds was lowest under $P$. halepensis litter and highest under $R$. lycioides litter, but no significant differences were found in germination rate between the other litter types. In this experiment, we found no effect of the mineral soil on the germination of $P$. lentiscus and B. retusum OK (Fig. 3, Table S1). When sown under the litter layer, we found a negative effect on the germination of $P$. lentiscus under $P$. halepensis litter, and the germination of B. retusum under Q. coccifera litter (Fig. 4, Table S2). In experiment 1 , germination was not affected by the provenance of the mineral soil, except for a reduction in $P$. lentiscus germination when sown on P. halepensis soil compared to other soil types (Fig. 1B, Table S1).

\subsection{Litter properties and seed germination}

Litter weight and thickness were strongly correlated (Table 3). Litter thickness correlated also to water holding capacity and hydrophobicity. Finally, litter weight correlated to hydrophobicity although weakly. Germination of $P$. lentiscus seeds under the litter was negatively related to litter weight (Table 3). Similarly, germination of both sown

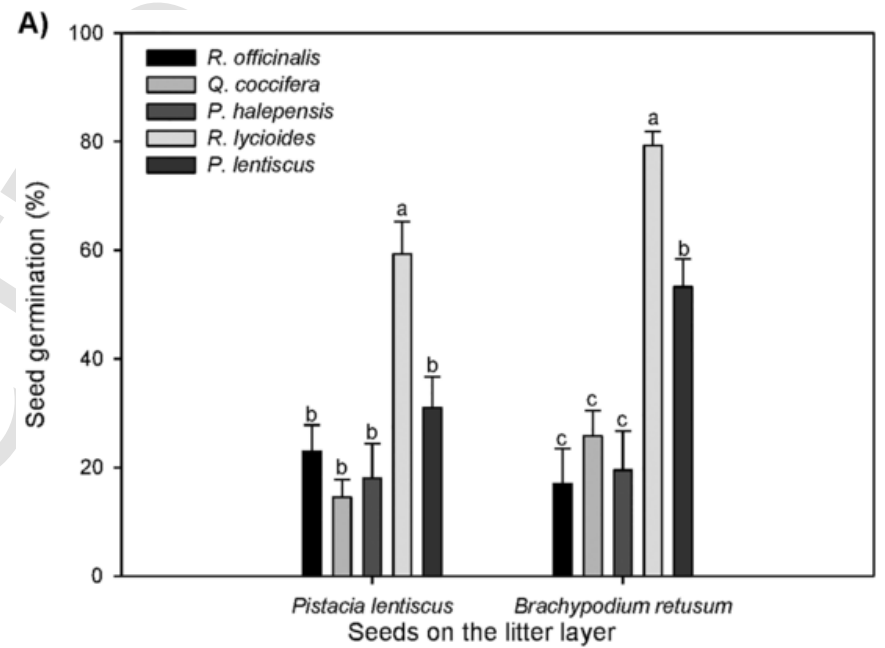

B)

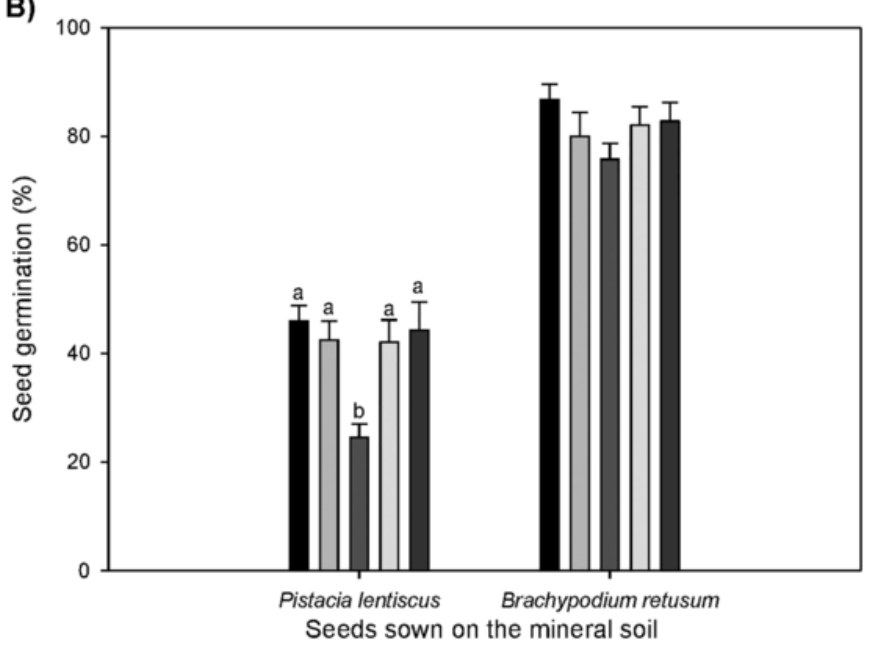

Fig. 1. Germination of Pistacia lentiscus and Brachypodium retusum seeds sown on the litter layer (A) and on the mineral soil (B) collected under five woody species. Means $\pm 1 \mathrm{SE}$ for $\mathrm{N}=8$ are shown. Different letters indicate significant differences. 


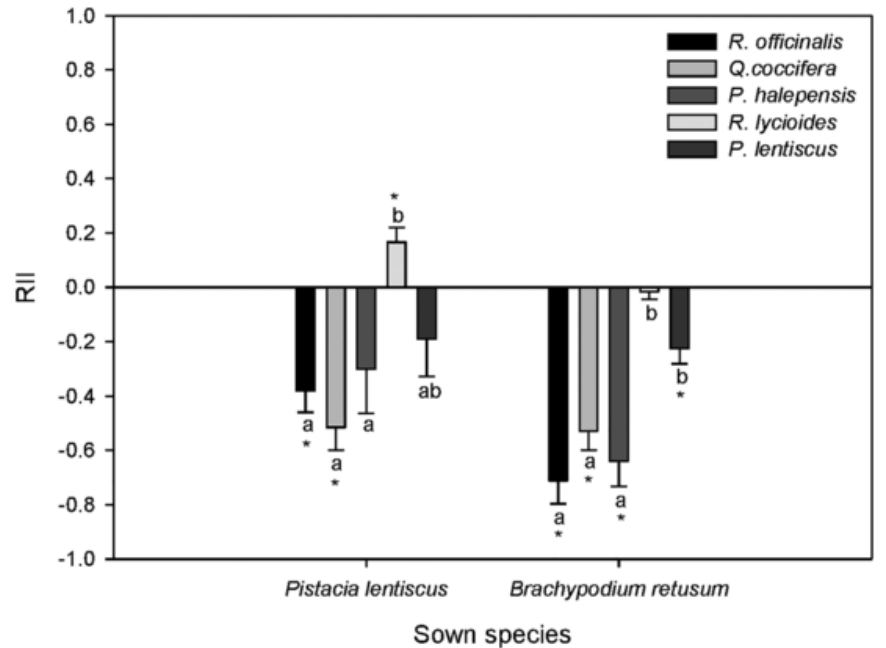

Fig. 2. Net effect (RII) of litter on germination of Pistacia lentiscus and Brachypodium retusum seeds when they were sown on top of the litter layer vs. the mineral soil devoid of litter. Means \pm 1SE for $N=8$ are shown. Different letters indicate significant differences for each sown species and seed location (ANOVA and Tukey-HSD test, $p<0.05$, Appendix Table S1). Asterisks indicate that differences between treatments are significantly different from zero (Student's t-test, $\mathrm{p}<0.05$, Table S2).

species on litter, and germination of $P$. lentiscus under the litter layer were negatively related to litter thickness. Germination rate was positively related to water holding capacity when seeds were sown on top of the litter layer, but showed no effect when seeds were sown under the litter. Finally, germination rate was not related to litter hydrophobicity.

\subsection{Litter extracts and seed germination}

Germination rate was high when seeds of both sown species where watered with litter extracts. We found no significant effect of litter extracts on germination rate (Figs. 5 and S1, Table S1).

\section{Discussion}

\subsection{Litter accumulation}

Average litter accumulation $\left(4.7 \mathrm{~kg} \mathrm{~m}^{-2}\right)$ was higher in our study sites than previously measured in other Mediterranean areas (e.g., 0.4-0.8 $\mathrm{kg} \mathrm{m}^{-2}$; Ferran et al., 2005; Santana et al., 2011). In drylands, litter distribution is patchy, being higher under vegetation patches and lower or absent in interpatch areas. Hence, estimations are commonly lower when the whole area, including interpatch areas, is taken into account. But our estimations are closer to those of studies employing similar methods (Fons, 1995, Baeza et al. Fundación CEAM, unpublished data).

Interspecific differences in litter accumulation reflect differences in plant lifespan and the balance between litter fall and litter decay. For example, $R$. officinalis, which showed relatively low litter accumulation, has a shorter lifespan than resprouting shrubs and trees (For example $Q$. coccifera and $P$. halepensis) that build up thicker litter layers (Capitanio and Carcaillet, 2008; Eugenio et al., 2012). Moreover, the decay rate of $R$. officinalis litter is higher than that of $P$. halepensis (Almagro and Martínez-Mena, 2012). Low litter accumulation under $R$. lycioides may be related to low litterfall inputs and relatively high decomposition rates. Finally, $P$. lentiscus litterfall inputs may be higher than $R$. lycioides inputs, which may contribute to the difference in litter accumulation (Lavado et al., 1989).
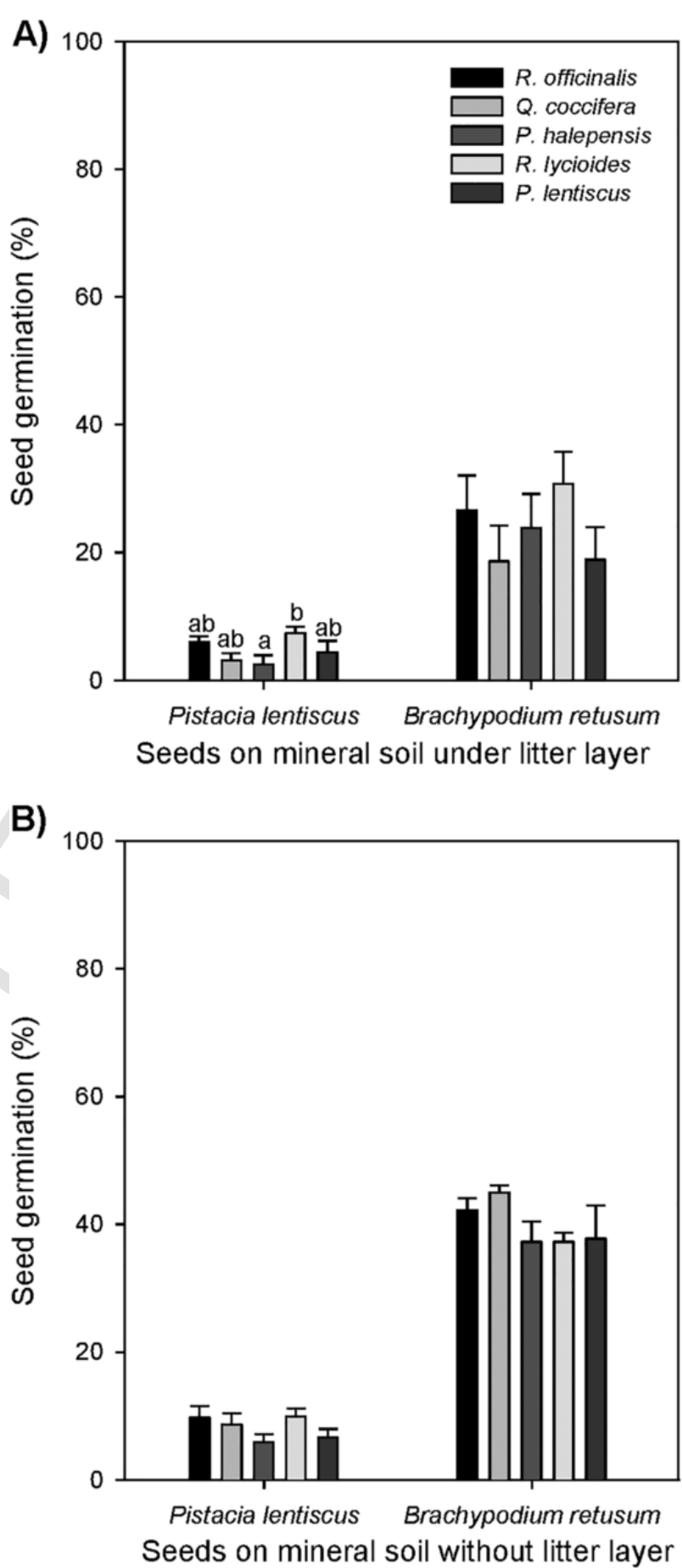

Fig. 3. Germination of Pistacia lentiscus and Brachypodium retusum seeds under the litter layer (A) and on mineral soil (B), collected under five woody species. Means $\pm 1 \mathrm{SE}$ for $\mathrm{N}=8$ are shown. Different letters indicate significant differences for each sown species and seed location (ANOVA and Tukey-HSD test, $\mathrm{p}<0.05$, see Appendix Table S1 for details).

\subsection{Effects of litter and litter extracts on germination}

The effect of litter on germination depended on litter type. In source species with high litter accumulation, as $P$. halepensis and Q. coccifera, litter had a negative effect on the germination of seeds located either on top or under the litter layer. This suggests the presence of physical barriers for germination, e.g. the litter layer may hamper soil-seed con- 


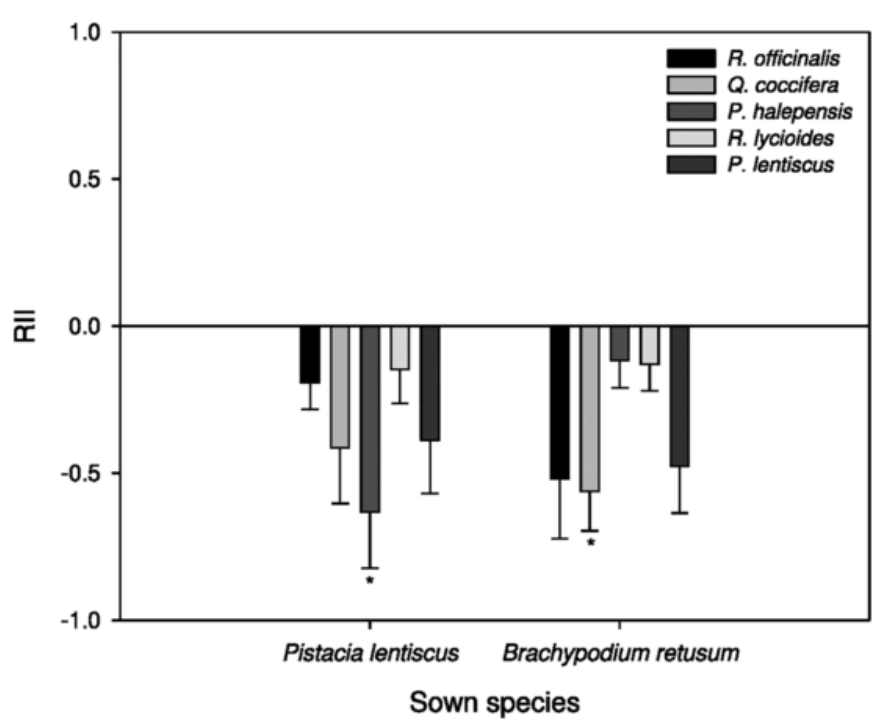

Fig. 4. Net effect (RII) of litter on germination of Pistacia lentiscus and Brachypodium retusum seeds when sown under the litter layer vs. sown on mineral soil devoid of litter. Means $\pm 1 \mathrm{SE}$ for $\mathrm{N}=8$ are shown. Asterisks indicate that differences between treatments are significantly different from zero (Student's t-test, $\mathrm{p}<0.05$, Table S2). We found no differences between treatments (See Appendix, Table S1 for ANOVA analyses).

tact and seed imbibition needed to initiate germination (Rotundo and Aguiar, 2005). In litter from species with lower litter accumulation, as $R$. officinalis, P. lentiscus and $R$. lycioides, the effect of litter on germination was heterogeneous, suggesting that other factors beyond litter thickness controlled seed germination. For example, the physical structure of the litter layer may affect seed germination (Donath and Eckstein, 2008). This probably explains the contrasted effect of $R$. lycioides litter vs. $R$. officinalis and $P$. lentiscus litter. Rosmarinus officinalis litter layer is compact, forming an intertwined network of litter fragments at different stages of decomposition. Pistacia lentiscus develops a dense mat of loose litter fragments. In contrast, the litter layer formed by $R$. $l y$ cioides is loose, leaving bare soil exposed. We propose that litter density hinders seed movement and prevents contact with the mineral soil in $R$. officinalis and P. lentiscus, compared to R. lycioides. Furthermore, the scarcity and loose morphology of the litter layer under $R$. lycioides may allow seed and seedling contact with the mineral soil. However, litter may also have negative effects on seed germination by modifying radiation income and quality, and intercepting rainfall. This later effect depends on rainfall amount and distribution, and seed location (Navarro-Cano et al., 2009; Villegas et al., 2010).

Water retention capacity of the litter layer may also influence seed germination, particularly when seeds are sown on top of the litter layer. In our study, $R$. lycioides litter was highly hydrophilic and had high water-holding capacity, but moisture accumulation under this species was scarce because litter accumulation is low. In contrast, $P$. halepensis and $Q$. coccifera litter show low water-holding capacity and high hydrophobicity, but it accumulates in large quantities. Our results contrast with studies showing no effect of litter cover on seed germina- tion under constant humidity (Eckstein and Donath, 2005). Other authors have reported a negative effect of litter on germination in the field (under variable moisture availability), and a positive effect of litter on germination in the laboratory (under constant moisture availability), which they attributed to water retention (Navarro-Cano et al., 2009). It must be noted that in our study, litter was regularly watered, and seeds located under the litter layer never dried out. Hence, we cannot infer the effect of litter under low water availability from our data, but our study shows an overall negative effect of litter on germination, and suggests that this effect is predominantly physical, and related to litter thickness and structure. These two factors, together with litter water-holding capacity, may be critical for germination in the absence of regular water inputs.

Surprisingly, the rate of germination of both sown species in Experiment 2 on mineral soil was lower than the germination rate on mineral soil in Experiment 1 and Experiment 3. We would have expected similar germination rates because seeds and treatments were similar. That could be caused by two factors: (1) the shorter duration of Experiment 2 and (2) the high temperatures in the laboratory during Experiment 2. The duration of our experiments was similar to other studies: previous experiments with $P$. lentiscus quantified seed germination after 28 days (García-Fayos and Verdú, 1998), and previous experiments with $B$. retusum quantified seed germination after 33 and 42 days (Bochet et al., 2007; Vidaller et al., 2018) and our experiments lasted until no germination was detected. Hence we propose that the higher temperatures caused the low germination rate.

Allelopathic effects on seed germination depend on seed species and may be proportional to litter abundance (Alrababah et al., 2009). Allelopathic effects on seed germination have been previously described for P. halepensis (Fernandez et al., 2008; Navarro-Cano et al., 2009), Q. coccifera (Alrababah et al., 2009; Fernandez et al., 2008; Navarro-Cano et al., 2009) and $R$. officinalis (Chen et al., 2013). Yet, the negative effect of litter on seed germination observed in our study was apparently unrelated to allelopathy. Indeed, the negative effect of litter was more intense when seeds were sown on top of the litter, compared to seeds sown under it or watered with litter extracts. Our results agree with observations showing no allelopathic effects of $P$. halepensis litter on P. lentiscus growth (Maestre et al., 2004). Methods used to expose seeds to litter extracts vary widely, increasing the challenge of deriving generalizations (Chen et al., 2013; Valera-Burgos et al., 2012). Thus, some studies on allelopathy used essential oils as they were aimed at agronomical applications (Angelini et al., 2003; Azirak and Karaman. 2008). Others used water extracts, but employed concentrated solutions (Valera-Burgos et al., 2012). Compared to those experiments, we used relatively diluted water extracts, which may resemble natural conditions more closely (Inderjit and Nilsen, 2003).

In our study, we evaluated the germination of seeds of two species differing in seed morphology and germination requirements (Espejo, 2007; García-Fayos et al., 2001). Yet, the effects of litter type and seed location on germination were similar in both species, suggesting that the effect of litter is independent of the sowed species, for the range of variability contemplated in our study. In contrast, the effect of

Table 3

Pearson's Correlation Coefficients between litter properties and germination rates. Data for all litter types were pooled. For Brachypodium retusum, $\mathrm{n}=22$. For Pistacia lentiscus, $\mathrm{n}=16$.

\begin{tabular}{|c|c|c|c|c|c|c|c|}
\hline & \multirow[t]{2}{*}{ Litter weight } & \multirow[t]{2}{*}{ Litter thickness } & \multirow[t]{2}{*}{ Water holding capacity } & \multicolumn{2}{|c|}{ Germination on litter Experiment 1} & \multicolumn{2}{|c|}{ Germination under litter Experiment 2} \\
\hline & & & & B. retusum & P. lentiscus & B. retusum & P. lentiscus \\
\hline Litter weight & 1.000 & - & - & -0.065 & -0.273 & -0.232 & $-0.656^{* *}$ \\
\hline Litter thickness & $0.734 * * *$ & 1.000 & - & $-0.501 *$ & $-0.537^{*}$ & -0.342 & $-0.745^{* * *}$ \\
\hline Water holding capacity & 0.007 & $-0.455^{* *}$ & 1.000 & $0.743^{* * *}$ & $0.760 * * *$ & -0.090 & 0.271 \\
\hline Hydrophobicity & $0.384^{*}$ & $0.586^{* * *}$ & -0.308 & -0.397 & -0.452 & -0.253 & -0.297 \\
\hline
\end{tabular}




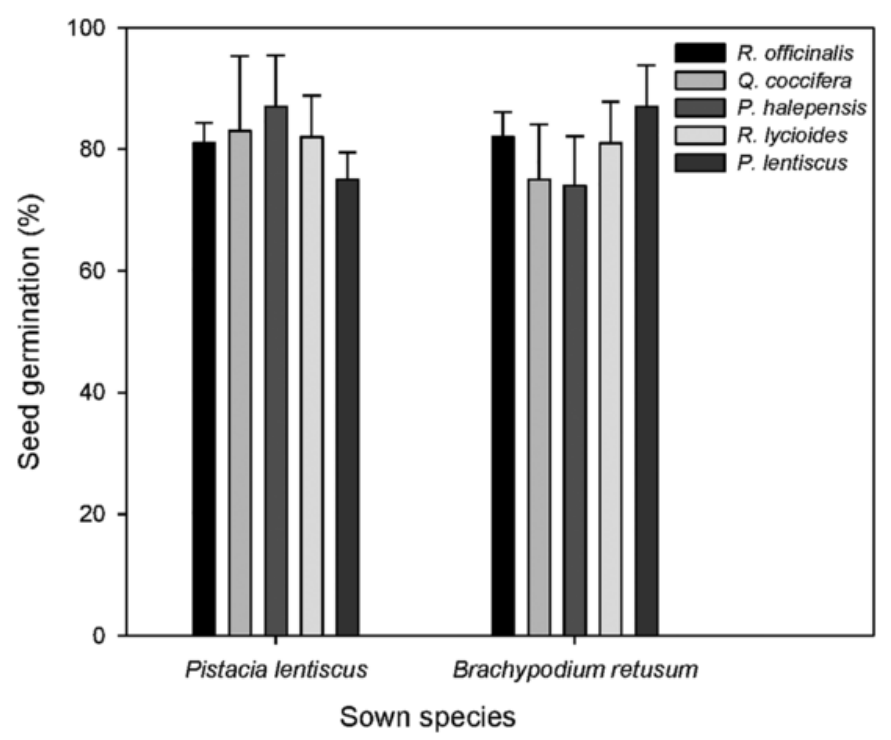

Fig. 5. Germination of Pistacia lentiscus and Brachypodium retusum sown on mineral soil and watered with litter extract from five woody species. Means \pm 1SE for $\mathrm{N}=8$ are shown. Differences in germination rate between the different litter extracts were not significant (ANOVA and Tukey-HSD test, $\mathrm{p}<0.05$, see Appendix Table S1 for details).

litter on seed germination was strongly dependent on seed location: litter had a strong and generalised negative effect on germination when seeds were sown on top of the litter layer, but showed no effect for most litter types and sown species when seeds were located under this layer.

\subsection{Implications on population dynamics, community composition and} management

The negative effect of litter on seed germination may have important consequences on population dynamics and community composition. As a result of litter interference, germination of species lacking mechanisms for long-distance seed dispersal may be reduced under adult individuals. Also litter interference may also represent a filter for the establishment of species attempting to colonize the patch (Gazol and Ibáñez, 2010; Tilman, 1993). According to our results, the five studied species have the ability to modulate seed germination by means of litter accumulation.

Being germination a key step in the life cycle, litter interference may have significant implications on competitive exclusion and the spatial distribution of vegetation. Our results contrast with studies showing a direct and positive relationship between abundance of woody resprouting plants and richness of vascular plants in Mediterranean steppes and shrublands (Maestre and Cortina, 2004a,b; Verdú and García-fayos, 1996a). Various processes may explain this disagreement. On the one hand, germination and recruitment could precede litter accumulation. For example, fire (Gómez-González and Cavieres, 2009), wildlife (Gutiérrez et al., 1997), soil fauna (Frouz et al., 2015) and humans (Sayer, 2006) remove litter opening windows for germination and seedling establishment. On the other hand, the negative effect of litter accumulation on germination could be offset by a positive effect of woody species on other phases of plant establishment, as woody species promote seed rain, particularly from ornitochorous species, and generate favourable microenvironments for seedling establishment (Amat et al., 2015; Castillo-Escrivà et al., 2019; Verdú and García-fayos, 1996b).

The positive impact of woody vegetation patches on community composition and ecosystem functioning has been a major argument to justify their use as nurse plants in restoration programs in semiarid areas (Cortina et al., 2012; Gómez-Aparicio et al., 2004). We have shown that litter does not contribute to this interaction and, indeed, it could have a negative effect on germination of the introduced species. This negative effect of litter may help to explain the idiosyncratic nature of plant-plant interactions in arid and semiarid areas (Maestre et al., 2009).

Given our results, mulching, a widely used eco-technological tool to protect soil in arid and semiarid areas, should be employed with caution, particularly when applied in combination with sowing. According to our results, and regardless of mulch structure and composition, application doses should not exceed $1.7 \mathrm{~kg} \mathrm{~m}^{-2}$ to avoid deleterious effects on germination. It is noteworthy that these dose is well above common recommended doses for commercial mulches in Spain $\left(0.1-0.2 \mathrm{~kg} \mathrm{~m}^{-2}\right.$; Projar, https://www.projar.es/) or used by previous authors $\left(0.2-0.6 \mathrm{~kg} \mathrm{~m}^{-2}\right.$, Bautista et al., 1996; Robichaud et al., 2013).

\section{Conclusions}

The effect of litter on germination depends on the abundance and structure of the litter layer, rather than the species sown. Results from this study highlight the important role that litter plays on seed germination in semiarid areas. The negative relationship between litter accumulation and seed germination may be attributed to a physical filter, and not to allelochemical interactions. The physical filter, together with the existence of multi-specific patches and high richness of vascular plants under woody patches suggests that litter accumulation and seed germination may be spatially or temporally segregated, or that the negative effect of litter is offset by positive interactions in other phases of plant establishment. These results have important implications on population and community dynamics in S. tenacissima steppes and other drylands, and on the restoration techniques aimed at the establishment of key species in these habitats.

\section{Financial support}

The authors appreciate funding from Ministry of Science, Innovation and Universities and European Regional Development Funds (FEDER), projects UNCROACH (CGL2011-30581-C02-01) and COSTERA (RTI2018-095954-B-I00).

\section{CRediT authorship contribution statement}

Tormo J: Validation, Formal analysis, Data curation, Writing - original draft, Writing - review \& editing, Visualization. Amat B: Conceptualization, Methodology, Formal analysis, Data curation, Writing - original draft, Writing - review \& editing, Visualization. Cortina J: Conceptualization, Methodology, Validation, Resources, Data curation, Writing - original draft, Writing - review \& editing, Supervision, Project administration, Funding acquisition.

\section{CRediT authorship contribution statement}

Tormo J: Validation, Formal analysis, Data curation, Writing - original draft, Writing - review \& editing, Visualization. Amat B: Conceptualization, Methodology, Formal analysis, Data curation, Writing - original draft, Writing - review \& editing, Visualization. Cortina J: Conceptualization, Methodology, Validation, Resources, Data curation, Writing - original draft, Writing - review \& editing, Supervision, Project administration, Funding acquisition.

\section{Declaration of competing interest}

The authors declare that they have no known competing financial interests or personal relationships that could have appeared to influence the work reported in this paper. 


\section{Acknowledgements}

We wish to thank María Joao Ribeiro Da Silva, Lucía de Soto, Lorena Guixot, Núria Jover, Adela Blasco, Alejandro Pastor and Elisa Cantán for their collaboration in the field work and to the referees for their valuable suggestions.

\section{Appendix A. Supplementary data}

Supplementary data to this article can be found online at https://doi. org/10.1016/j.jaridenv.2020.104258.

\section{References}

Almagro, M, Martínez-Mena, M, 2012. Exploring short-term leaf-litter decomposition dynamics in a Mediterranean ecosystem: dependence on litter type and site conditions. Plant Soil 358, 323-335. doi:10.1007/s11104-012-1187-6.

Alrababah, M A, Tadros, M J, Samarah, N H, Ghosheh, H, 2009. Allelopathic effects of Pinus halepensis and Quercus coccifera on the germination of Mediterranean crop seeds. N. For. 38, 261-272. doi:10.1007/s11056-009-9145-8.

Amat, B, Cortina, J, Zubcoff, J J, 2015. Community attributes determine facilitation potential in a semi-arid steppe. Perspect. Plant Ecol. Evol. Systemat. 17, 24-33. doi:10.1016/j.ppees.2014.10.001.

Angelini, L G, Carpanese, G, Cioni, P L, Morelli, I, Macchia, M, Flamini, G, 2003. Essential oils from Mediterranean Lamiaceae as weed germination inhibitors. J. Agric. Food Chem. 51, 6158-6164. doi:10.1021/jf0210728.

Armas, C, Ordiales, R, Pugnaire, F I, 2004. Measuring plant interactions: a new comparative index. Ecology 85, 2682-2686. doi:10.1890/03-0650.

Azirak, S, Karaman, S, 2008. Allelopathic effect of some essential oils and components on germination of weed species. Acta Agric. Scand. Sect. B Soil Plant Sci 58, 88-92. doi:10.1080/09064710701228353.

Baraza, E, Zamora, R, Hódar, J A, 2006. Conditional outcomes in plant-herbivore interactions: neighbours matter. Oikos 113, 148-156. doi:10.1111/ j.0030-1299.2006.14265.x.

Bautista, S, Abad, N, Llovet, J, Bladé, C, Ferran, A, Ponce, J M, Caturla, R N, Alloza, J A, Bellot, J, Vallejo, V R, 1996. VIII. Siembra de herbaceas y aplicación de mulch para la conservación de suelos afectados por incendios forestales. In: Vallejo, V R (Ed.), La restauración de la cubierta vegetal en la Comunidad Valenciana. CEAM 395-234.

Bochet, E, García-Fayos, P, Alborch, B, Tormo, J, 2007. Soil water availability effects on seed germination account for species segregation in semiarid roadslopes. Plant Soil 295, 179-191. doi:10.1007/s11104-007-9274-9.

Boeken, B, Orenstein, D, 2001. The effect of plant litter on ecosystem properties in a Mediterranean semi-arid shrubland. J. Veg. Sci. 12, 825-832.

Bonanomi, G, Sicurezza, M G, Caporaso, S, Esposito, A, Mazzoleni, S, 2006. Phytotoxicity dynamics of decaying plant materials. New Phytol. 169 (3), 571-578. doi:10.1111/ j.1469-8137.2005.01611.x.

Bosco, T, Bertiller, M B, Carrera, A L, 2018. Abiotic factors affect the recruitment and biomass of perennial grass and evergreen shrub seedlings in denuded areas of Patagonian Monte rangelands. J. Environ. Manag. 218, 118-128. doi:10.1016/ j.jenvman.2018.04.020.

Brearley, F Q, Press, M C, Scholes, J D, 2003. Nutrients obtained from leaf litter can improve the growth of dipterocarp seedlings. New Phytol. 160 (1), 101-110. doi:10.1046/j.1469-8137.2003.00851.x.

Callaway, R M, Nadkarni, N M, Mahall, B E, 1991. Facilitation and interference of Quercus douglasii on understory productivity in central California. Ecology 72, 1484-1499. doi:10.2307/1941122.

Capitanio, R, Carcaillet, C, 2008. Post-fire Mediterranean vegetation dynamics and diversity: a discussion of succession models. For. Ecol. Manag. 255, 431-439. doi:10.1016/j.foreco.2007.09.010.

Castillo-Escrivà, A, López-Iborra, G M, Cortina, J, Tormo, J, 2019. The use of branch piles to assist in the restoration of degraded semiarid steppes. Restor. Ecol. 27, 102-108. doi:10.1111/rec.12704.

Castro, J, Zamora, R, Hódar, J A, Gómez, J M, Gómez-Aparicio, L, 2004. Benefits of using shrubs as nurse plants for reforestation in mediterranean mountains: a 4-year study. Restor. Ecol. 12, 352-358.

Chen, F, Peng, S, Chen, B, Ni, G, Liao, H, 2013. Allelopathic potential and volatile compounds of Rosmarinus officinalis L. against weeds. Allelopathy J. 32, 57-66.

Cortina, J, Amat, B, Castillo, V M, Fuentes, D, Maestre, F T, Padilla, F M F M, Rojo, L, 2011. The restoration of vegetation cover in the semi-arid Iberian southeast. J. Arid Environ. 75, 1377-1384. doi:10.1016/j.jaridenv.2011.08.003.

Cortina, J, Maestre, F T, 2006. Plant effects on soils in drylands: implications for community dynamics and ecosystem restoration. In: Binkley, D, Menyailo, O (Eds.), Tree Species Effects on Soils: Implications for Global Change. Berlin/Heidelberg, Springer-Verlag, pp. 85-118. doi:10.1007/1-4020-3447-4_6.

Cortina, J, Ruiz-Mirazo, J, Amat, B, Amghar, F, Bautista, S, Chirino, E, Derak, M, Fuentes, D, Maestre, F T, Valdecantos, A, Vilagrosa, A, 2012. Bases para la restauración ecológica de espartales. Gland, Suiza y Málaga, España., IUCN. International Union for Conservation of Nature.
Dekker, L W, Ritsema, C J, 1994. How water moves in a water repellent sandy soil: 1. Potential and actual water repellency. Water Resour. Res. 30, 2507-2517. doi:10.1029/94WR00749.

Descheemaeker, K, Muys, B, Nyssen, J, Poesen, J, Raes, D, Haile, M, Deckers, J, 2006. Litter production and organic matter accumulation in exclosures of the Tigray highlands, Ethiopia. For. Ecol. Manag. 233 (1), 21-35. doi:10.1016/ j.foreco.2006.05.061.

Doblas-Miranda, E, Sánchez-Piñero, F, González-Megías, A, 2009. Different microhabitats affect soil macroinvertebrate assemblages in a Mediterranean arid ecosystem. Appl. Soil Ecol. 41, 329-335. doi:10.1016/j.apsoil.2008.12.008.

Donath, T W, Eckstein, R L, 2008. Grass and oak litter exert different effects on seedling emergence of herbaceous perennials from grasslands and woodlands. J. Ecol. 96, 272-280. doi:10.1111/j.1365-2745.2007.01338.x.

Eckstein, R L, Donath, T W, 2005. Interactions between litter and water availability affect seedling emergence in four familial pairs of floodplain species. J. Ecol. 93, 807-816. doi:10.1111/j.1365-2745.2005.01015.x.

Espejo, D, 2007. Brachypodium retusum (Pers.) Beauv.(Poaceae), una espècie d'interès per a la recuperació d'espais degradats mediterranis. Quaderns Agraris 31, 85-107.

Eugenio, M, Olano, J M, Ferrandis, P, Martínez-Duro, E, Escudero, A, 2012. Population structure of two dominant gypsophyte shrubs through a secondary plant succession. J. Arid Environ. 76, 30-35. doi:10.1016/j.jaridenv.2011.07.001.

Facelli, Jose M, Pickett, S T A, 1991. Plant litter: light interception and effects on an old-field plant community. Ecology 72 (3), 1024-1031. doi:10.2307/1940602.

Facelli, Pickett, S T A, 1991. Plant litter: its dynamics and effects on plant community structure. Bot. Rev. 57 (1), 1-32. doi:10.1007/BF02858763.

Facelli, Pickett, S T A, 1991. Indirect effects of litter on woody seedlings subject to herb competition. Oikos 62 (2), 129-138. doi:10.2307/3545257.

Fernandez, C, Voiriot, S, Mévy, J-P, Vila, B, Ormeño, E, Dupouyet, S, Bousquet-Mélou, A, 2008. Regeneration failure of Pinus halepensis Mill.: the role of autotoxicity and some abiotic environmental parameters. For. Ecol. Manag. 255, 2928-2936. doi:10.1016/ j.foreco.2008.01.072.

Ferran, A, Delitti, W, Vallejo, V R, 2005. Effects of fire recurrence in Quercus coccifera L. shrublands of the Valencia Region (Spain): II. plant and soil nutrients. Plant Ecol. 177, 71-83. doi:10.1007/s11258-005-2141-y.

Fons, J, 1995. Avaluació de la fertilitat de sòls forestals mediterranis. El cas de les pinedes de pi blanc (Pinus halepensis Mill.). PhD. Universitat de Barcelona.

Frouz, J, Roubíčková, A, Heděnec, P, Tajovský, K, 2015. Do soil fauna really hasten litter decomposition? A meta-analysis of enclosure studies. Eur. J. Soil Biol. 68, 18-24. doi:10.1016/j.ejsobi.2015.03.002.

García-Fayos, P, Verdú, M, 1998. Soil seed bank, factors controlling germination and establishment of a Mediterranean shrub: Pistacia lentiscus L. Acta Oecol. 19, 357-366. doi:10.1016/S1146-609X(98)80040-4.

García-Fayos, P, Gulias, J, Martínez, J, Marzo, A, Melero, J P, Travesset, A, Veintimilla, P, Verdú, M, Cerdán, V, Gasque, M, Medrano, H, 2001. Bases ecológicas para la recolección, almacenamiento, y germinación de semillas de especies de uso forestal de la Comunidad Valenciana. In: García-Fayos, P (Ed.), Valencia, Banc de Llavors Forestals (CMA, Generalitat Valenciana).

García-Guzmán, G, Benítez-Malvido, J, 2003. Effect of litter on the incidence of leaf-fungal pathogens and herbivory in seedlings of the tropical tree Nectandra ambigens. J. Trop. Ecol. 19 (2), 171-177.

Garnett, E, Jonsson, L M, Dighton, J, Murnen, K, 2004. Control of pitch pine seed germination and initial growth exerted by leaf litters and polyphenolic compounds. Biol. Fertil. Soils 40, 421-426. doi:10.1007/s00374-004-0801-z.

Gazol, A, Ibáñez, R, 2010. Variation of plant diversity in a temperate unmanaged forest in northern Spain: behind the environmental and spatial explanation. Plant Ecol. 207 (1), 1-11. doi:10.1007/s11258-009-9649-5.

Gómez-Aparicio, L, Zamora, R, Gómez, J M, Hódar, J A, Castro, J, Baraza, E, Hodar, J A, 2004. Applying plant facilitation to forest restoration : a meta-analysis of the use of shrubs as nurse plants. Ecol. Appl. 14, 1128-1138.

Gómez-González, S, Cavieres, L A, 2009. Litter burning does not equally affect seedling emergence of native and alien species of the Mediterranean-type Chilean matorral. Int. J. Wildland Fire 18, 213. doi:10.1071/WF07074.

Gutiérrez, J R, Meserve, P L, Herrera, S, Contreras, L C, Jaksic, F M, 1997. Effects of small mammals and vertebrate predators on vegetation in the Chilean semiarid zone. Oecologia 109, 398-406. doi:10.1007/s004420050099.

Herranz, J M, Ferrandis, P, Copete, M A, Duro, E M, Zalacaín, A, 2006. Effect of allelopathic compounds produced by Cistus ladanifer on germination of 20 Mediterranean taxa. Plant Ecol. 184 (2), 259-272. doi:10.1007/s11258-005-9071-6.

Holmgren, M, Scheffer, M, Huston, M A, 2010. The interplay of facilitation and competition in plant communities. Ecology 78, 1966-1975.

Hurlbert, S H, 1997. Functional importance vs keystoneness: reformulating some questions in theoretical biocenology. Austral Ecol. 22, 369-382. doi:10.1111/ j.1442-9993.1997.tb00687.x.

Inderjit, Nilsen, E T, 2003. Bioassays and field studies for allelopathy in terrestrial plants: progress and problems. Crit. Rev. Plant Sci. 22, 221-238. doi:10.1080/713610857.

Kavvadias, V A, Alifragis, D, Tsiontsis, A, Brofas, G, Stamatelos, G, 2001. Litterfall, litter accumulation and litter decomposition rates in four forest ecosystems in northern Greece. For. Ecol. Manag. 144 (1-3), 113-127. doi:10.1016/S0378-1127(00)00365-0.

Lamb, E G, 2008. Direct and indirect control of grassland community structure by litter, resources, and biomass. Ecology 89 (1), 216-225. doi:10.1890/07-0393.1.

Lavado, M, Nuñez, E, Escudero, J C, 1989. Variaciones mensuales en el aporte de biomasa al suelo por distintas especies de matorral mediterráneo. In: Bellot, J (Ed.), Jornadas sobre las bases ecológicas para la gestión en ecosistemas terrestres. CIHEAM, pp. 167-172 (Zaragoza). 
López-Barrera, F, González-Espinosa, M, 2001. Influence of litter on emergence and early growth of Quercus rugosa: a laboratory study. N. For. 21 (1), 59-70.

Maestre, F T, Bautista, S, Cortina, J, Bellot, J, 2001. Potential for using facilitation by grasses to establish shrubs on a semiarid degraded steppe. Ecol. Appl. 11, 1641-1655. doi:10.1890/1051-0761.

Maestre, F T, Callaway, R M, Valladares, F, Lortie, C J, 2009. Refining the stress-gradient hypothesis for competition and facilitation in plant communities. J. Ecol. 97, 199-205. doi:10.1111/j.1365-2745.2008.01476.x.

Maestre, F T, Cortina, J, 2004. Insights into ecosystem composition and function in a sequence of degraded semiarid steppes. Restor. Ecol. 12, 494-502. doi:10.1111/ j.1061-2971.2004.03106.x

Maestre, F T, Cortina, J, 2004. Do positive interactions increase with abiotic stress? A test from a semi-arid steppe. Proc. R. Soc. Lond. Ser. B Biol. Sci. 271 (Suppl. 1_5), S331-S333. doi:10.1098/rsbl.2004.0181.

Maestre, F T, Cortina, J, Bautista, S, 2004. Mechanisms underlying the interaction between Pinus halepensis and the native late-successional shrub Pistacia lentiscus in a semi-arid plantation. Ecography 27, 776-786. doi:10.1111/j.0906-7590.2004.03990.x.

Navarro-Cano, J A, 2007. Reclutamiento vegetal en pinares de repoblación y espartales en ambientes semiáridos: aplicaciones a la restauración ecológica. PhD Dissertation. Universidad de Murcia.

Navarro-Cano, J A, Barberá, G G, Ruiz-Navarro, A, Castillo, V M, 2009. Pine plantation bands limit seedling recruitment of a perennial grass under semiarid conditions. J. Arid Environ. 73, 120-126. doi:10.1016/j.jaridenv.2008.09.002.

Navarro, R M, 2006. Factores que afectan al éxito de una repoblación y su relación con la calidad de la planta. In: Cortina, J, Peñuelas, J L, Puértolas, J, Vilagrosa, A, Savé, R (Eds.), Calidad de Planta Forestal Para La Restauración En Ambientes Mediterráneos. Estado Actual de Conocimientos. Organismo Autónomo Parques Nacionales. Ministerio de Medio Ambiente, Madrid, Spain.

Noble, A D, Randall, P J, 1999. Alkalinity effects of different tree litters incubated in an acid soil of N.S.W., Australia. Agrofor. Syst. 46 (2), 147-160. doi:10.1023/ A: 1006299615488.

Pausas, J G, Bonet, A, Maestre, F T, Climent, A, 2006. The role of the perch effect on the nucleation process in Mediterranean semi-arid oldfields. Acta Oecol. Int. J. Ecol. 29, 346-352. doi:10.1016/j.actao.2005.12.004.

Pugnaire, F I, Padilla, F, 2006. The role of nurse plants in the restoration of degraded environments. Front. Ecol. Environ. 4, 196-202.

R Development core team, 2018. R: A Language and Environment for Statistical Computing.

Reader, R J, 1993. Control of seedling emergence by ground cover and seed predation in relation to seed size for some old-field species. J. Ecol. 81 (1), 169-175. doi:10.2307/ 2261232.

Rivas-Martínez, S, Rivas-Sáenz, S, Penas, Á, 2011. Worldwide bioclimatic classification system. Glob. Geobotany 1, 1-634.

Robichaud, P R, Lewis, S A, Wagenbrenner, J W, Ashmun, L E, Brown, R E, 2013. Post-fire mulching for runoff and erosion mitigation. Catena 105, 75-92. doi:10.1016/ j.catena.2012.11.015.
Rolo, V, Amat, B, Cortina, J, 2016. Water availability and species identity control shrub colonization in abandoned semiarid steppes. Agric. Ecosyst. Environ. 228, 62-69.

Rotundo, J L, Aguiar, M R, 2005. Litter effects on plant regeneration in arid lands: a complex balance between seed retention, seed longevity and soil-seed contact. J. Ecol. 93, 829-838. doi:10.1111/j.1365-2745.2005.01022.x.

Ruprecht, E, Enyedi, M Z, Eckstein, R L, Donath, T W, 2010. Restorative removal of plant litter and vegetation 40 years after abandonment enhances re-emergence of steppe grassland vegetation. Biol. Conserv. 143 (2), 449-456. doi:10.1016/ j.biocon.2009.11.012.

Santana, V M, Baeza, M J, Vallejo, V R, 2011. Fuel structural traits modulating soi temperatures in different species patches of Mediterranean Basin shrublands. Int. J. Wildland Fire 20, 668. doi:10.1071/WF10083.

Sayer, E J, 2006. Using experimental manipulation to assess the roles of leaf litter in the functioning of forest ecosystems. Biol. Rev. 81 (1), 1-31. doi:10.1017/ S1464793105006846.

Sparks, D L, Page, A L, Helmke, P A, Loeppert, R H, Nelson, D W, Sommers, L E, 1996. Total carbon, organic carbon, and organic matter. In: Page, A L (Ed.), Methods of Soil Analysis. Part 2. Chemical and Microbiological Properties. Madison. WI. American Society of Agronomy USA. doi:10.2136/sssabookser5.3.c34.

Tilman, D, 1993. Species richness of experimental productivity gradients: how important is colonization limitation? Ecology 74, 2179-2191. doi:10.2307/1939572.

Tracol, Y, Gutiérrez, J R, Squeo, F A, 2011. Plant Area Index and microclimate underneath shrub species from a Chilean semiarid community. J. Arid Environ. 75, 1-6. doi:10.1016/j.jaridenv.2010.08.002.

Valera-Burgos, J, Díaz-Barradas, M C, Zunzunegui, M, 2012. Effects of Pinus pinea litter on seed germination and seedling performance of three Mediterranean shrub species. Plant Growth Regul. 66, 285-292. doi:10.1007/s10725-011-9652-4.

Verdú, M, García-fayos, P, 1996. Nucleation processes in a Mediterranean bird-dispersed plant. Funct. Ecol. 10, 275-280.

Verdú, M, García-fayos, P, 1996. Post dispersal seed predation in a mediterranean patchy landscape. Acta Oecol. Int. J. Ecol. 17, 379-391.

Vidaller, C, Dutoit, T, Ibrahim, Y, Hanslin, H M, Bischoff, A, 2018. Adaptive differentiation among populations of the Mediterranean dry grassland species Brachypodium retusum: the role of soil conditions, grazing, and humidity. Am. J. Bot. 105, 1123-1132. doi:10.1002/ajb2.1116.

Villegas, J C, Breshears, D D, Zou, C B, Law, D J, 2010. Ecohydrological controls of soil evaporation in deciduous drylands: how the hierarchical effects of litter, patch and vegetation mosaic cover interact with phenology and season. J. Arid Environ. 74, 595-602. doi:10.1016/j.jaridenv.2009.09.028.

Whitford, W G, 2002. Ecology of Desert Systems. Academic Press.

Yuan, J, Liang, D, Zhang, S, 2016. Litter and its interaction with standing vegetation affect seedling recruitment in Tibetan alpine grasslands. Plant Ecol. Divers. 9, 89-95. doi:10.1080/17550874.2015.1073400. 